\title{
Signatures and Popular Literacy in Early Seventeenth-century Japan
}

\author{
RUBINGER, Richard*
}

\begin{abstract}
My paper looks at "signatures" in the form of "ciphers" (kao) and other personal marks made on population registers, town rules, and apostasy oaths in the early seventeenth century to provide some empirical evidence of very high literacy among village leaders. The essay also argues, using the same data, that literacy had already begun to spread to household heads, particularly those in cities as well as to farming communities that were engaged in commerce. Signatures on documents--never before used for literacy study in Japan as far as I know--also provide some hints of early literacy among women in commercial farming families. Wide differences in the spread of literacy in cities and in the rural areas of the country are also clearly evident in these documents through analysis of signatures and other personal marks made on oaths and petitions.
\end{abstract}

One important reason for the paucity of literacy (as compared to school attendance) studies in Japan has certainly been the belief that systematic data, such the signature data widely used in Western studies of literacy, are unavailable in Japan. The extensive use of engraved seals or chops (known in Japan by a variety of terms such as inkan, hanko, inshô) on documents in place of individually scrawled signatures is no doubt one of the compelling factors involved. This paper explores the possibilities of using signature data for literacy study in early seventeenth-century Japan. ${ }^{1}$

Western scholars have defined three elements that are essential for an appropriate standard of literacy measurement. The standard must be: (1) universal, covering all ages, classes, sexes and occupations; (2) consistent; and (3) direct, specifically measuring ability to read and or write in ways that the circulation of books and school attendance do not. Since personal signatures satisfy these requirements, signature data has been highly touted and widely used to measure literacy in Western history. ${ }^{2}$ In England and France especially, signatures on wedding registers, available in great quantity over many years, have been used as the standard of measurement of basic literacy among the populace. ${ }^{3}$

To be sure, there are problems with such a method. Signatures would seem to measure only the barest, most rudimentary skill. Furthermore, how would signatures indicate ability to read as

\footnotetext{
* Indiana University

e-mail address: rubinge@indiana.edu
} 
opposed to write? In the case of wedding registers in particular, there are cases where a literate bride accompanying an illiterate groom followed the man in making a mark in the register rather than embarrass him by signing when he could not. And there is the famous case of William Shakespeare's father John, a town merchant and official, who had the habit of marking documents with an " $\mathrm{X}$ " rather than his signature.

Two prominent French scholars, Francois Furet and Jacques Ozouf, set out to test the reliability of signature data as a measure of basic literacy. They took an extensive survey of signatures on wedding registers (compulsory in France since 1667) compiled by Louis Maggiolo in 1879-80 and compared it with data from the national census begun in 1886 and with conscription data for men compiled since 1827. Both the census and the conscription data provided information on those unable to either read or write, those able to read only, those able to read and write, and those who failed to comply (a negligible quantity). They submitted these three different yet convergent sources on French educational levels in 1866 to factorial and comparative analysis. The result was "a remarkable correlation between the ability to read and write (for men and women) and signatures on marriage registers." "Despite some inconsistency in reporting among departements and some apparent under-representation of towns, they concluded that "the ability to sign one's name does indeed refer to what we now call literacy, which in turn means reading and writing" and that "the signature is a good test of literacy."

Are signature data, then, having satisfied the basic requirements of a universal, consistent, and direct measure and having been found to be statistically valid as a measure of basic literacy, really of no use in the Japanese case? In the Meiji period (1868-1912) a few prefectures surveyed their populations as early as the 1880 s, querying specifically the ability to sign. Later, the Ministry of the Army (Rikugunshô) included a category entitled "ability to read and write one's name" on its conscription exams, providing a solid database for measuring literacy and illiteracy beginning in 1899. But how useful are signature data for earlier periods? Can data be found for the seventeenth century, for example? Here the answer is both yes and no.

\section{The Database}

Japan has one of the most complete databases of population information in the world, one that goes back much earlier than the French census and even predates the seventeenth-century French signature requirement on wedding registers. It consists of the shûmon aratame-chô or "religious affiliation inquiry registers" used from the early seventeenth into the middle of the nineteenth century to certify that every individual Japanese--man, woman, and child--was a member of a Buddhist temple which guaranteed that none was affiliated with Christianity in any way. This system of registration eventually, in the early Meiji period, became the basis for the permanent residence registration (koseki) system, a bureaucratic practice that is still in use. Shûmon aratamechô have been used extensively by demographers to examine changes in population, migration in and out of villages, and family and marriage patterns during the Tokugawa period. ${ }^{6}$

In 1640 the shogunate instituted a governmental department called Shûmon Aratame Yaku (Office of Religious Inquisition), which became the central agency for supervising measures meant to eradicate Christianity throughout Japan. The surveillance process put into effect by this office took the form of compilation of "religious affiliation inquiry registers". At first, compilation of the registers was confined to the approximately one quarter of the country under the direct rule of the 
Tokugawa shogun. In 1665, however, the Tokugawa shogunate ordered all domanial lords to compile registers; in 1671, it made than an annual requirement. From then on all residents of Japansamurai, farmers, and townspeople-were registered under the system every year. Not all of these documents have survived, but many from different parts of the country have. According to Hayami Akira, the population registers collected and studied thus far are only a small percentage of those probably extant and still located in the storehouses of descendants of Tokugawa village officials. $^{7}$

Religious Affiliation Registers listed everyone in the village or town on the day it was compiled in the sixth lunar month of each year. The documents were prepared for each village by a single individual, usually the headman or a designated scribe, so there are no individual signatures. Furthermore, from about the middle of the seventeenth century, just as the registration system was becoming a countrywide endeavor, carved seals were coming into general use throughout the country as marks of individual identification. These seals provide few clues as to the writing ability of individuals whose names appeared on these documents. Their pervasive use is one of the main reasons for overlooking signature data in studies of literacy in Japan.

However, prior to the time when seals became widely used, documents exist that list names of villagers and townspeople followed not with seals but with a variety of individually written personal marks certifying understanding and agreement with the text of the document. There are apostasy oaths that pre-date the shûmon aratame-chô called nanban kishômon. Typically, as is the case with later Religious Affiliation Registers, every name in the village was attached, not just those of headmen or household heads. Unlike the shûmon aratame-chô, they do not indicate a person's affiliation with a Buddhist temple. The document simply required an oath certifying that one was not Christian. In addition, there are various kinds of village and town rules (sadame) going back to the fourteenth century that set out regulations that "signers" are required to follow. Typically, only representatives-household heads in towns or village officials-would certify these materials, but they were individually validated by a mark in the principal's own hand.

Thus, documents exhibiting a variety of personal marks are available for the Japanese case, making empirical judgments about levels of literacy in early Tokugawa history possible. Documents limited to the elite levels of the commoner classes go back to an even earlier time. The best materials, those that have the names of all or virtually all of the residents of a village or town names attached, are of a much shorter duration, a mere several decades in the seventeenth century. They can be used to assess literacy levels in selected populations of commoners during a brief window of opportunity from the first apostasy oaths until the widespread use of seals - from the 1630 s up to about 1650 .

\section{Ciphers (kaô)}

The most reliable of the various marks, from the perspective of estimating literacy, is the cipher, or monogram $(k a \hat{o})$. Ciphers began as signatures and evolved into unique designs used for personal identification. Typically, they were formed by combining one or two characters from a personal name into a simple but highly individual mark used for purposes of certification. In the eighth and ninth centuries, official documents emanating from the central state organ, the Dajôkan, were authenticated with a carved or engraved seal (inkan), following Chinese practice. Non-official documents, both public and private, were signed. Signatures by officials on public documents 
were usually in the formal, standard script and were quite legible. For private business, however, one was free to write in a more creative, cursive form, permitting stroke order and the basic shapes of characters to be altered to the point where they were no longer recognizable. These highly individualized, often illegible signatures eventually came to be called kaô. The word is a compound of two Chinese characters meaning impressing a flower, indicating a signature, artfully and beautifully rendered, like a flower. Although "monogram" may be the more familiar term, I believe "cipher" to be the better English approximation.

Ciphers began to appear in Japan at the beginning of the Heian period (794-1185), around the time that the hiragana syllabary was being developed by a similar process of abbreviating Chinese characters and writing them in cursive form. During that period kaô were artistic signatures favored by the highly literate members of the court aristocracy and were based typically upon the actual characters of a person's name. With the rise of the military class to national power in the Kamakura period, there developed new ciphers that were designs based upon characters. In the case of Minamoto no Yoritomo, founder of the Kamakura shogunate, for example, the left side of "Yori" and the right side of "tomo" were joined to form his distinctive kaô.

The founder of the Tokugawa shogunate, Tokugawa Ieyasu (1543-1616), preferred a style of cipher that had originated in the Ming dynasty and was called Minchôtai in Japanese. Its basic feature was a simple design drawn between two parallel lines. Ieyasu was followed in this practice by most ranking members of the warrior class and eventually by the upper levels of the commoners, as will be seen below. By the end of the rule of the eighth Tokugawa shogun, Yoshimune (1684-1751; r. 1716-1745), toward the middle of the eighteenth century, it was customary to have kaô designs carved into a wooden seal from which rubbings could be taken. Ciphers then lost their original meaning and function and became little different in usage from seals. They had, in fact, already gone out of fashion by the middle of the seventeenth century, when feudal authorities began to insist that standardized carved seals be used to certify documents. In 1873 the Meiji government ruled that seals be impressed on important documents, and kaô were seldom used thereafter. They are seldom seen today except when ministers of the government, following tradition, attach their kaô to important legislation agreed to in committee before submitting it to the National Diet for ratification. ${ }^{8}$

A look at original documents of the early seventeenth century makes it clear immediately that ciphers were individually written and required considerable skill with a brush to produce. It does not seem unreasonable to suggest that ability to write a bona fide kaô was an indication of ability to write (and probably to read) at a fairly high level. It is, of course, possible that someone could master a cipher and not be able to write, just as someone could sign his name and be able to write nothing else. But mastery of the writing brush is difficult and requires extensive practice. Anyone who could produce a finely written $k a \hat{o}$ would almost certainly be able to write more extensively, although there could have been exceptions.

\section{Marks for Illiterates and Semi-Illiterates}

By the Edo period there had developed not only ciphers for those who wrote well but a whole range of marks that could be used by illiterates and semi-literates. Some were of very old vintage, like the "finger measure" (or kakushi), which enabled illiterate men to certify divorce papers by checking off on a document the spaces between knuckles of their forefinger. There were 
other types as well. At about the time that "finger measures" began to disappear during the Heian period, some farmers began to use what scholars now call "abbreviated ciphers" (ryakuô). These ranged in design from a simplified version of a cipher to a simple mark that is no more than a circle, occasionally with a dot in the center. Some of these exhibit something of the individualized character of the personal cipher. The more elaborate examples suggest a limited ability with the brush; the simple circular types, probably not. ${ }^{9}$

From the end of the Kamakura period, a crude "stem stamp" (fude jikuin) method of marking began to appear beneath the names of commoners on documents, although not in large numbers at first. This was a mark made by dipping the reverse end of the brush stem (or handle) into ink and then impressing a mark on paper. Although some scholars claim that these marks, too, may be made with a characteristic personal touch by the way they are rolled or imprinted, it is clear that they required no ability to write. Stem stamps appear to have been used heavily by the illiterate sectors of the commoner classes, particularly but not exclusively women and children, until the early eighteenth century or so. They, too, gave way to seals around the middle of the Edo period.

Tsume-in (fingernail impression) was another type of mark used by illiterates. It was made by dipping the edge of a fingernail in ink and pressing it on paper. It was sometimes used in criminal cases when a commoner did not have a seal and could not write. As a rule, young girls did not carry seals and often used either fingernail marks or stem stamps. Blood marks (keppan; the marks of bloodied hands) are also occasionally seen as marks of authenticity on commoners' documents of the Tokugawa period, as are thumb prints (boin). Needless to say, neither of these marks required the ability to write.

During the Tokugawa period it was possible for one person to substitute for another in signing or certifying a document, as a mother for an infant, or a household head for an under-aged child. In Osaka, a proxy was used until a child reached the age of fourteen. At fifteen, the child was considered competent to "sign." When a proxy was used, however, the proxy's name also had to be indicated with a certifying stamp.

\section{Literacy in Urban Households I: Signatures on Town Rules in Kyoto}

The Kyoto City Historical Archives (Kyôto Rekishi Shiryôkan) houses a collection of "Town Rules" (sadame) from the commercial inner city wards of the city, home to wealthy merchants like the Mitsui family from the late sixteenth to the early nineteenth centuries. ${ }^{10}$ The Rules were fashioned by local town councils following requirements set by higher feudal authorities and included the names of all household heads in the ward followed by a validating mark. The existence of detailed rules themselves shows how early in the Tokugawa period urban areas were developing strategies for independence and local rule. They are surprisingly comprehensive, covering many areas of city life, suggesting extensive local administrative oversight by the early seventeenth century.

Rules for Kyoto wards show the kinds of identifying marks made by household heads over time. Cipher use among household heads in commercial wards in the early years, through 1624, was extremely high. In Niwatorihôkô-chô in 1596 out of a total of 59 names, 47 or 80 percent confirmed that they had read and understood the Rules by "signing" with an elegant cipher after their name. In 1620 in Shimohonnôjimae-chô all but one household head used a kaô, a 95 percent 
cipher usage rate among household heads in that ward. In the same ward in 1634 the rate was still over 50 percent with 10 out of 19 using a cipher. In those wards where a distinction was made between homeowners and renters, such as in Reizei-chô in 1614, homeowners--who were responsible for paying taxes and for reading and understanding the various town regulations--showed substantially higher rates of kaô use (75 percent) than did renters who themselves had a reasonably high 55 percent rate of cipher use.

Town and village rules are useful because they provide an early record, going back into the late sixteenth century, of individualized commoner marks on documents. They provide impressive evidence that the upper levels of the urban merchant class were highly literate very early in the Tokugawa period, and for decades before that. The data here further show that this was not just true of the very top echelons of the town leadership class (machidoshiyori) who were roughly equivalent in status and function to village headmen. The high literacy group who could "sign" with elegant and elaborate ciphers also included a very high percentage of household heads, a much more significant number than the number of town officials. It must be kept in mind, however, that this data is from a prosperous and wealthy commercial sector of the major city in the country at the time.

\section{Literacy in Urban Households II: Rokkaku-chô, Kyoto (1635)}

A fuller accounting of the population in one of these wealthy commercial wards of Kyoto is provided in an apostasy oath sworn to by every resident, not just household heads in Rokkakuchô in central Kyoto. Like most of these documents the oath and the names that followed were written by a single hand. The certifying marks following names, however, were individually written and allow us to make some tentative remarks about levels of literacy among ages, sexes, and statuses revealed both within and among households.

Since the Muromachi period the Rokkaku-chô ward of Kyoto had been home to wealthy Kyoto merchants such as the Mitsui family. In 1635 the Kyoto deputy (shoshidai) ordered that all residents swear an oath or pledge that they were not Christians and affix a certifying mark below their names to that effect. These apostasy oaths (nanban kishomon) were not limited to heads of households. They included the name of every resident-man, woman, and child (except infants under five)-in the town. Unlike later religious affiliation registers, no Buddhist temple affiliation was indicated on the nanban kishomon.

Each page of the Rokkaku-chô document is devoted to a single household. ${ }^{11}$ Most of these households had employees and these are included on a separate line below that of family members. In addition, the status of family members--wife, mother, older brother and so forth--is usually indicated in the document. Gender was not indicated directly, but the names of female employees were invariably written in the phonetic hiragana syllabary whereas male names were almost always written in Chinese characters. All these indicators, direct and indirect, allow us to make some inferences about literacy distinctions within families and among the population of this ward.

The format of the pledges was similar to what later would be followed in the religious affiliation registers. Everyone, including servants, was listed as a member of a household. Within each household the household head was invariably listed first, followed by other members, roughly in order of their nearness to him (occasionally her), taking sex and age into account. Thus, names of fathers and mothers immediately followed the household head, followed by name of a spouse, 
then those of siblings and children in age order. Renter households in the ward were recorded separately, allowing us to make that basic but nonetheless useful distinction.

Although many commoners had family names they were not permitted to use them on legal documents, so only given names were used. Adult women were typically entered without any name, with just their status as wife, mother and occasionally widow (goke) indicated. The exception to this was female servants who were listed by their given names, invariably written in hiragana. Ages were not entered, unlike some later religious affiliation registers.

Nineteen of the twenty-six heads of homeowner households in Rokkaku-chô in 1635, that is, 73 percent, used a cipher ( $k a \hat{o})$ to certify their names. If two widows who used seals are discounted, the relative number would be 79 percent. In either case, this percentage is about the same or higher than that found in other prosperous commercial wards of Kyoto at the same time. In Shimohonnôjimae-chô, for example, 53 percent of homeowner household heads used ciphers in 1634.

But this document, unlike Town Rules, makes it clear that headmen were not the only members of the community with the literacy skill to write ciphers. In Rokkaku-chô in 1635, in addition to household heads, brothers, nephews, some employees, and a few women used ciphers. This suggests that at least in the urban areas, a much broader population than seen before had considerable skill with a brush in the very first decades of the Tokugawa period.

Adult women overwhelmingly used seals to certify their names. Of twenty wives, eighteen (or 90 percent) preferred this method, eight of eleven ( 73 percent) of mothers used it, and half of the fourteen daughters used seals. The two wives who did not use seals used stem stamps, but two of the mothers used ciphers, and one used a simple cipher mark made with a brush, possibly indicating some rudimentary literacy. The seven daughters who did not use seals used stem stamps. These could have been younger girls who were as yet untutored. The older girls could have followed their mothers and used seals.

The diversity of these markings clearly suggests a very wide range in literacy skills among female family members, not illiteracy across the board. At one end of the spectrum of skills there were several senior women who, by their use of ciphers, were apparently highly skilled. They would, in all likelihood, have been trained prior to the Tokugawa period in a household that was actively engaged in commerce as almost all of these families were. At the other end, were the younger girls who used stem stamps and were probably illiterate. The use of seals by an overwhelming percentage of wives could mean that many adult women were involved in commercial transactions for which the seal was becoming the certifying stamp of choice by this time. Or, the seal could be an indicator of illiteracy, there is no sure way to know. In urban commercial households like these, however, it is more likely that the stem stamp rather than the seal was the mark of choice for those unable to read and write.

Two out of the three fathers in the document used ciphers; the other pressed a seal. Of the nine nephews and uncles, five used ciphers, and four used seals. 10 out of 23 sons (43 percent) used ciphers. The rest were split between seals (30 percent) and stem stamps ( 21 percent). The latter group could very well have been quite young, hence the stem mark which could have been made on their behalf. The older sons who did not use ciphers could have been shifting to the use of seals, as some merchants were probably doing. One of the sons made an abbreviated cipher of the creative type. If we assume that the stem stamp was the mark of a very young child and exclude them from our calculations, the percentage of sons who were literate cipher users goes from a respectable 43 percent to an impressive 56 percent. Of the other twelve non-household head 
males (including nephews of indeterminate age) seven (58 percent) used ciphers. Using this figure and that for sons one might argue that cipher as reflected in this document suggests that literacy skills in commercial families were passing down from father to son and, at the same time, extending outward beyond household heads to other adult males and a very limited number of adult females.

Of the employees working in these households, 63 were males and 58 were females. 43 percent or 27 of the 63 males used ciphers, indicating a high level of writing skill. 29 percent of male employees, most likely young children, used stem stamps and were presumably illiterate. The cipher users must have been older apprentices who kept accounts and maintained written records and needed substantial literacy skills. The 20 percent who made abbreviated ciphers with a brush might have been a step above the group at the bottom but nowhere near the level of skill of cipher users. If this group had some level of literacy, albeit low, and we added their 20 percent to the 43 percent of cipher users, we get 63 percent of male employees with some level of literacy. This would leave about 30 percent illiterate if the personal mark estimates made here are roughly accurate.

By the same measure, 62 percent of female employees would have been illiterate. There were, however, two wet nurses among the female employees who were cipher users. At a far more rudimentary level of literacy skill, 12 out of the 58 female employees ( 21 percent) used abbreviated ciphers. 8 of the girls, 14 percent of the total, used seals. Thus, there could have been something like 25 percent of the female employees with some degree of literacy, while the overwhelming majority was probably very young and illiterate. The percentages of high and low skills among females are roughly the reverse of the males. Among employees, as among family members, male literacy appears much higher. Male employees were older and more likely to be engaged in work that required some literacy. The girls seem to be younger and were probably babysitters and mothers' helpers who did not require such skills. But indications of a diversity of female literacy skills at all levels is noteworthy. The evidence of cipher use among some women suggesting a high level of skill is particularly remarkable for this early period.

These data on cipher use point to surprisingly high levels of literacy within urban commercial families at a very early point in early modern Japan, if our assumptions about certifying marks as indicators of literacy levels are anywhere near accurate. Household heads, their fathers, their sons, and their employees show high levels of literacy skill by 1635 , as indicated by cipher use. This confirms, at least for urban areas, our earlier judgment based on circumstantial evidence that the circle of literacy had extended beyond the narrow core of leaders early in the seventeenth century.

The extensive use of seals among adult women and their daughters makes it difficult to assess their skills, but it is worthwhile noting that among owner households, a few adult women, both family members and employees, showed substantial writing skills. Evidence for literacy among women this early is very difficult to find, so even the few cases found here of cipher use among women must be regarded as suggestive of a phenomenon that could have been more widespread in urban commercial families.

At the same time, however, the evidence here also suggests very strongly (if stem stamps are an accurate guide) that illiteracy was generally much higher among women than men. This was particularly so among younger women employees, as might be expected. 


\section{Signature Data in a Tokugawa Farming Village: Tomooka Village (1635)}

All the data seen so far have been from inner city wards. What about signature data from villages in the early Tokugawa period? Religious affiliation registers and apostasy oaths for villages during the short period when personal marks appeared on them are hard to come by. An apostasy oath similar to that for Rokkaku ward and for the same year is available, however, for a farming village on the outskirts of Kyoto, Tomooka. This village, located in what is now in the southernmost section of Nagaokakyô City, was situated just off the main highway that linked Osa$\mathrm{ka}$ and Kyoto in the Tokugawa period. It was mainly an agricultural village but had a small commercial section, called Chaya, separated physically from the main village that consisted of a number of households that ran small businesses serving travelers along the highway. The physical separation of agricultural villages from small commercial sectors was not unusual for the area. ${ }^{12}$

There is a beautifully preserved very early apostasy oath (nanban kishômon) for 1635 (Kan'ei 12), housed in the Nagaokakyô Library, which lists all of the 71 residents of Tomooka Village that year. ${ }^{13}$ The apostasy oath was sent out to villages by the Kyoto Shoshidai. The final text, prepared by a single hand, presumably the village headman or other official, was followed by a list of the names or statuses (in the case of adult women) of every member of the village. Each villager had to certify that he (or she) understood the content of the oath and: (1) was not now a believer in Christianity or would ever would ever become one and would never encourage others to do so; (2) if he should ever break the oath he (or she) would suffer the afflictions of both Western and Buddhist infernos.

There are twenty-three households in all, including one Buddhist priest. The priest (belonging to an unregistered temple, the document notes) appears to have been the only one who wrote his name himself, because both his name and his large bold cipher are noticeably different from the rest. On this particular document only household heads and a few genin (employees or servants) made marks; women and children did not. The number of children's names seems quite small (nineteen children for twenty-three households), and it is possible that the names of younger children were omitted. The names are divided into three categories: ordinary farmers, residents of Chaya (who may have been separated in the document because they were relative newcomers ${ }^{14}$ ), and inkyo (literally "retired" persons but best understood here to mean "irregular" households).

Of the twenty-three households, fifteen were headed by ordinary farmers, with fifty people listed in all. Four households and thirteen people lived in the Chaya commercial section; and four households comprising eight people were classified as "irregulars." This last category consisted of widows (who could not head a household) with sons not yet married, making such a household other than "regular." The priest was also included in this group. In addition to these three categories, part of the formal organization of the village, additional status distinctions can be derived from the various individual marks made following each name.

The village headman and two of the household heads from Chaya verified their names with seals. The headman, Kuzaemon, used the oval-shaped, design-type seal without characters or name, one characteristic of early Tokugawa-period commoners' seals. Kuzaemon had the largest household in the village. In addition to him, it included his wife, mother, a young son named Tori, and two genin, Kyûbei and Yosaku. He was obviously the leading farmer in the village and in all likelihood had both administrative responsibilities and commercial interests. Two Chaya merchant household heads also used seals that were common at this time-one a six-sided irregularly shaped seal, the other fan-shaped. The use of seals by the village headman and two of the Chaya mer- 
chants in this village does not directly reveal anything about their literacy. But their occupations and involvement in commerce suggest considerable ability in that regard.

The only ones to use ciphers in Tomooka were the priest, named Nensai, and one household head, named Kyûzaemon. Priests were the intellectuals of the early Tokugawa period and it is not surprising that a priest would use a bold and powerful cipher as an indication of learning, or that it would stand apart from the marks made by ordinary farmers. Kyûzaemon, both because he is listed in the document immediately next to the headman Kuzaemon and because of the similarity of their names, is almost certainly the older son of the village headman. The document shows that he married, established a household of his own, and had a son. His use of a cipher indicates that he was a member of the village elite. In 1642, seven years later, another Tomooka village document listed him as a village toshiyori (elder) alongside Kuzaemon, presumably his father, who was still the headman. ${ }^{15}$ Kyûzaemon's cipher was a mark both of his status in the village and of the relatively high level of literacy that would accompany such a position.

The other household heads in the village, nineteen of them, used the most basic form of abbreviated cipher, a circle made with a brush. Five or six of these are so simple as to be indistinguishable from a stem stamp. Three genin (employees) chose to make identical marks as those of household heads, that is, simple circles following their names. Women and children made no marks at all. This is most unfortunate, for had the groups assumed here to have been illiterate used stem stamps, a higher level of skill might be ascribed to the circle drawn with a brush. This could have been the case in the Rokkaku-chô materials where illiteracy, I believe, was indicated by marks of some sort--stem stamps, dots, nail prints--where no facility with the brush was needed.

It is tempting, then, to suggest that where no mark at all was the indicator of illiteracy, the simple circle, used in this instance by household heads, marked a higher, although still very rudimentary, level of literacy. On the other hand, the case could also be made (as in the instance of the other documents) that the inscription of circles meant nothing more than that these headmen could hold a brush and make a mark equivalent to the " $\mathrm{X}$ " made by illiterates in Western countries; in other words, that they had no literacy skills at all. Interpretation is difficult because the marks are circles, making it impossible to tell even whether the "writer" could set and remove the brush from paper properly. Women and children in early farming communities, it would appear, were so far on the cultural and political periphery that they did not verify documents at all. Adult women, like their big city sisters, did not have their names on the documents, only their status, as wife or mother. Children had their status--as son or daughter--plainly indicated but also their names, written less conspicuously, smaller and off to the side or beneath their status designation.

Despite the simplicity of this early village document and the difficulty of reading meaning into it, a few things are evident. There are clear distinctions of status and literacy skill suggested by the personal marks on this early rural document abjuring the Christian faith. Ciphers were used, but only by a very few, a priest and the older son of the headman; they almost certainly signified advanced literacy skills and pre-eminent status in the village. Those in the commercial sector and the headman used seals, a mark, in some cases such as this one, of entrepreneurial or administrative engagement. The overwhelming number of ordinary male household heads and the few employees listed used simple circles. Although the literacy implications of these circles may be hard to assess, the difference in writing skill between ordinary household heads in a rural community and those in a large city is dramatic. Urban/rural differences with respect to female literacy also stand out. In Tomooka, in contrast to Kyoto, women made no marks on these documents, suggesting not just that they were illiterate but that they were irrelevant as far as the official world was 
concerned.

\section{Conclusion}

This paper has presented some sources that are new to the study of literacy--population registers and anti-Christian oaths from the brief period between 1630 and about 1650 when individuals in towns and villages made personal marks certifying that they had understood the content of the documents. The variety of individual marks found on these documents, left behind by communities of commoners from the early seventeenth century, ranges from elaborate ciphers to such indicators of illiteracy as dots, circles, fingernail marks, thumbprints, and stem stamps, revealing important differences in literacy skills within families, among families, between genders, and between cities and villages. Admittedly, the documentary evidence that has been adduced is inadequate and the time span covered too brief to allow for firm generalizations. The goal here has been to squeeze as much meaning as possible from these limited materials in the belief that future discovery of additional signature data will help to fill out this sketch of literacy among the early Tokugawa period's commoners. ${ }^{16}$

Based on the signature data in large urban centers like Kyoto presented in this paper, a high percentage of household heads were not just literate but functioning at a high administrative level as measured by the use of ciphers on a variety of documents. This suggests that in urban centers, both large and small, central and geographically peripheral, literacy had spread widely, beyond the few top-level ward leaders, among the much larger group of household heads.

In commercial wards of Kyoto literacy had spread to about half of the sons of household heads, to male employees, to fathers, nephews, and uncles, and, in a few cases, to adult women. Although the evidence was limited to only a few examples, it is possible that the trends shown were widespread in the largest cities. If so, it argues for a very high level of literacy among a significant portion of the early seventeenth-century urban population.

Consider, too, that Japan in the early seventeenth century was going through one of the greatest ages of urban development the world had ever seen. During the years of Nobunaga and Hideyoshi in the late sixteenth century, castle towns sprang up "like toadstools," with some ninety built between 1572 and $1590 .{ }^{17}$ When Ieyasu required that each domain limit itself to one castle town, the urban population became even more concentrated. Between 1580 and 1610 nearly half of today's largest Japanese cities came into being as castle towns, and about 10 percent of the population of a given domain lived in them. By the end of the seventeenth century, 140 castle towns had populations of more than five thousand, approximately half of them artisans and merchants. Edo stood at close to one million, Osaka had 365,000 and the population of Kyoto was over $300,000 .{ }^{18}$ Thus, the core literate population of these urban centers, even if only household heads are considered, could have included a sizable number.

The apostasy oath from tiny Tomooka Village confirms that even in farming villages there were a few highly skilled community leaders who performed administrative and commercial tasks. The document also reinforces the notion that village populations were divided into "two cultures"--a very small elite at the top who were literate and an overwhelming majority who were not. In Tomooka the latter in all probability included most male heads of households. Outside the village leadership, women, older children, employees, and servants--making up the substantial part of village populations--remained largely illiterate in the seventeenth century, judging by the marks 
they made on documents.

In larger villages and among more commercially oriented villagers, those nearer to large cities or closer to transportation links, literacy may well have spread to leaders of five-household groups and to some household heads. But here, too, cipher-like marks on an abundance of rules and regulations appear to be limited to village leaders.

Nevertheless, the appearance of an elite, highly literate leadership in rural areas is significant. Not only can indications of literacy be found in a relatively early period, it was of a high functional level--not just the rudimentary type of skills that writing schools would later produce. Village leaders were reading and writing documents of various kinds little different from their samurai betters in the castle towns. And, if Tomooka represents small villages around the country the numbers of highly literate farmers may not have been inconsiderable even early in the Tokugawa period. The point is that there was a significant group in the countryside capable of high level administrative tasks, a core around which localities could further enrich their cultural and commercial possibilities.

What do the high level of functional literacy among the elite of the commoner classes and the limited nature of its spread to the general populace suggest? They indicate, first of all, that the pervasive use of administrative instruments, which scholars such as Aoki Michio are continually uncovering in early Tokugawa villages, was probably restricted to the village elite and should not be taken to suggest a growing commoner constituency for literacy, at least not in the early seventeenth century. The popular base of learning and literacy almost certainly did not expand until later. The extensive use of administrative documents points not to a growing literate population but to the depth and expertise of a restricted elite.

Second, the findings presented here suggest that literacy developed in Tokugawa Japan not alongside or as a result of the growth of schools but well before the appearance of educational institutions for commoners. Thus, just as the national school system of the Meiji era had to contend with an unequally educated populace when it was first imposed in 1872, so, too, were diverse patterns of literacy and learning already, to some degree, in place or in process when commoner schools first began to proliferate in the late-eighteenth and early nineteenth centuries.

Notes

1 This paper is based on Chapter Two of the author's forthcoming book from University of Hawaii Press, entitled, Popular Literacy in Early Modern Japan (February 2007).

2 R. S. Schofield, "The Measurement of Literacy in Pre-Industrial England," in Jack Goody, ed., Literacy in Traditional Societies (Cambridge: Cambridge University Press, 1968): 318-319.

3 The classic study of literacy in England is Lawrence Stone, "Literacy and Education in England 1640-1900," Past and Present, no. 42 (February 1969):69-139. On France the work that has influenced me the most has been, Francois Furet and Jacques Ozouf, Reading and Writing: Literacy in France from Calvin to Jules Ferry (Cambridge: Cambridge University Press, 1982).

4 Furet and Ozouf, Reading and Writing, p.16.

5 Ibid., pp.17-18. There was actually a negative correlation between signatures and "reading alone" as opposed to "reading and writing." This causes more problems of interpretation in the French case, where reading tended to be taught two or three years prior to writing, than in the Japanese case, where reading and writing were usually taught simultaneously or writing was taught first.

6 In English see especially Akira Hayami, The Historical Demography of Pre-Modern Japan (Univ. of Tokyo Press, 1997).

7 L. L. Cornell and Akira Hayami, "The shûmon aratame-chô: Japan's Population Registers," Journal of Family History, Vol. 11, no. 4 (1986): 315.

8 Conversation with Prof. Kasaya Kazuhiko at Nichibunken in Kyoto, November 2000.

9 The term "ryakuô" in Japanese printed texts includes both types. Therefore, it is essential to look at the original document to ascertain (or to estimate) the likelihood of literacy skill from these marks. 
10 The catalogue of this collection is available in published form as Kyôto-shi Rekishi Shiryôkan, comp., Kyôto machi shikimoku shûsei: sôsho Kyôto no shiryô 3 (Kyoto: Kyôto-shi Rekishi Shiryôkan, 1999). The catalogue provides not only lists of original documents in the collection, but translations into modern Japanese of the texts with all names and marks in printed form, vastly simplifying the task of deciphering them.

11 The original document is part of the Kita Kannonyama-chô (Rokkaku-chô) monjo (file \#135) housed in the Kyoto Historical Archives (Kyôto Rekishi Shiryôkan).

12 Conversation with Igeta Shôji, professor emeritus of Doshisha University, Feb. 25, 2001.

13 "Tomooka mura hyakushô Nanban kishômon," is part of "Tomooka Tatsuo-ke monjo," and housed in the Nagaokakyô City Library. I wish to thank Ms. Momose Chidori, a specialist at the libary and Prof. Igeta Ryôji for their help in providing access to this rare local document and in helping me interpret it. The document can be found in printed form in Nagaokakyô-shi Shi Hensan Iinkai, ed., Nagaokakyô-shi shi shiryôhen 3 (Nagaokakyô Shiyakusho, 1993): 83-84.

14 Nagaokakyô-shi Shi Hensan Iinkai, comp., Nagaokakyô-shi shi (Kyoto: Nagaokakyô Shiyakusho, 1997) honbuhen vol. 2 , p. 41 .

15 "Tomooka mura hattô" (Rules of Tomooka Village) 1642 in "Tomooka Tatsuo-ke monjo" in Tomooka City Library and available in printed form in Nagaokakyô-shi shi shiryôhen 3, pp. 85-86.

16 A study group, "shikiji kenkyûkai," led by Professor Ôto Yasuhiro of Tsukuba University and made up of Professors Yakuwa Tomohiro of Niigata University, Kimura Masanobu of Chikushi Jogakuen University, Suzuki Rie of Nagasaki University, Jurgis Elisonas of Indiana University, Richard Rubinger of Indiana University, Umemura Kayo of Nara University of Education, Ôta Motoko of Saitama Prefectural University, and Amano Haruko of Japan Women's University has met twice, once in Tokyo and more recently in Bloomington, Indiana for the purpose of collecting and analyzing the personal marks placed on documents in order to better understand the complex nature of literacy among non-elites in premodern Japan. They have collected data in a working paper entitled, "Zen kindai Nihon in okeru shikiji jôkyô in kansuru kisoteki kenkyû," put out under the auspices of Tsukuba Daigaku Daigakuin Ningen Sôgô Kagaku Kenkyûka (March 2006).

17 Conrad Totman, Early Modern Japan (University of California Press, 1993): 63.

18 James L. McClain, A Modern History of Japan (W. W. Norton and Co., 2002): 51-54. 